\title{
Deriving Vignettes for the Rare Disease AADC Deficiency Using Parent, Caregiver and Clinician Interviews to Evaluate the Impact on Health-Related Quality of Life
}

This article was published in the following Dove Press journal:

Patient Related Outcome Measures

\author{
Andria Hanbury (D) \\ Adam B Smith ${ }^{\prime}$ \\ Katharina Buesch ${ }^{2}$ \\ 'York Health Economics Consortium, \\ University of York, York YOI0 5NQ, UK; \\ ${ }^{2}$ PTC Therapeutics, Zug 6300, \\ Switzerland
}

\begin{abstract}
Purpose: Aromatic 1-amino acid decarboxylase (AADC) deficiency is a rare genetic condition, characterised by movement disorder, and speech and cognitive functioning impairment. To enable economic evaluation of treatments, health-related quality of life or utilities need to be derived. These are currently lacking in the literature. This is challenging, where patient numbers are small, particularly in paediatric populations. This study outlines the 5-stage development of vignettes describing AADC, for use in a subsequent health-state utility elicitation study, with an emphasis on caregiver and clinician engagement.
\end{abstract}

Methods: To align with the economic model, 5 vignettes describing 5 AADC deficiency motor milestones were developed, ranging from "bedridden" to "walking with assistance". Stage 1 comprised identification of symptoms/impairments from the literature and AADC deficiency charity websites. Stage 2 comprised group discussion with 3 caregivers. A symptoms matrix was developed, followed by draft vignettes (Stage 3). Eight clinicians reviewed these, alongside the same 3 caregivers via a survey (Stage 4). The vignettes were revised at stage 5.

Results: There was high consensus regarding symptoms at Stages 1 and 2, although the literature highlighted behavioural and autonomic symptoms, which caregivers did not. The symptoms were grouped into neuromuscular, autonomic, cognitive, behavioural and functional impairments. Clinician and caregiver vignette feedback highlighted the idiopathic nature of AADC. Despite this, clinicians suggested only 2 additional symptoms. Similarly, caregivers suggested 4 symptoms and a change to the wording used for the cognitive symptoms. Not all changes were included.

Conclusion: The differing focus of caregivers, clinicians and the literature reinforces the importance of patient/caregiver engagement. The vignettes need to comprehensively capture what it is like to live with AADC deficiency, in order for the subsequent utilities to be robust. A focus on evidence triangulation, especially for idiopathic conditions, and how engagement is sought from caregivers are important future avenues of research.

Keywords: aromatic 1-amino acid decarboxylase deficiency, AADC deficiency, vignettes, caregivers, clinicians

\section{Introduction}

Aromatic l-amino acid decarboxylase (AADC) deficiency is a rare genetic condition with only around 140 cases reported worldwide to date. ${ }^{1}$ AADC deficiency is caused by mutations in the gene encoding the enzyme AADC which is responsible for the formation of the neurotransmitters, serotonin and dopamine. It is
York Health Economics Consortium,

Enterprise House, Innovation Way,

University of York, York YOIO 5NQ, UK

Tel +44 (0) 1904323620

$\mathrm{Fax}+44(0) 1904323628$

Email adam.smith@york.ac.uk
Patient Related Outcome Measures 2021:12 I-12

DovePress if in 
characterised by movement disorder, including the loss of voluntary movement, hypotonia and intermittent oculogyric crises (OGC). Speech and cognitive functioning may also be affected. Around $80 \%$ of cases are categorised as severe, ${ }^{1}$ meaning the patient is bedridden for life, fails to achieve developmental milestones and is fully dependent. Mild and moderate cases have also been recorded (representing $5 \%$ and $15 \%$ of cases, respectively). ${ }^{1,2}$ Mild to moderate cases respond to drug treatment such as, dopamine agonists and monoamine oxidase B (MOA-B) inhibitors, aimed at reducing symptoms through correcting serotonin and catecholamines deficiencies. For severe cases, this is not the case. However, an emerging onetime gene therapy which supports the production of key neurotransmitters has been shown to be a promising new treatment. $^{3}$

Alongside demonstrating the clinical efficacy of AADC deficiency therapy, cost-effectiveness (CE) studies are stipulated by certain health technology assessment (HTA) agencies to help inform reimbursement decisions. In the United Kingdom (UK), for instance, the National Institute for Health and Care Excellence (NICE) requires $\mathrm{CE}$ studies to include a measure of health-related quality of life (HRQoL) in the form of health utilities. For the UK, health utilities have to be derived, where possible, from preference-based instruments, such as the EQ-5D-3L. ${ }^{4}$ Utility scores - which typically range from 0 (equivalent to dead) to 1 (perfect health) - represent societal preferences for a given health state. Health states considered worse than death are also possible (utility score $<0$ ). However, given the nature and rarity of AADC deficiency it is not possible for patients to complete instruments like the EQ-5D-3L. The robustness of proxy scores derived from parents or caregivers may also be questioned, again owing to the few cases globally. Therefore, other approaches, such as time trade-off (TTO), standard gamble $^{5}$ (SG) and discrete choice experiments ${ }^{6}$ (DCE), are required. The first approaches typically present vignettes describing health states to participants who then are either instructed to indicate the hypothetical amount of life they would be willing to trade in return for the remaining time in perfect health (TTO) or the level of risk of treatment failure they would be willing to accept in exchange for a cure (SG); health state utilities are then provided by 1-(number of years traded/10) or 100-(risk of failure/100).

The aim of this study was to develop a number of TTO and SG vignettes for subsequent use in obtaining health state utilities for AADC deficiency. The vignettes were developed using input from a number of sources, including parents of AADC deficiency patients, as well as clinicians.

\section{Methods}

Initial considerations were whether to design the vignettes from the child's or parent's perspective. Direct utility elicitation using TTO and SG can be challenging for rare diseases involving children. If the child perspective is taken, the subsequent valuation by the adult general population can become difficult, especially if certain symptoms are related to development milestones, such as crawling. If the parent/carer perspective is taken, the health states need to be carefully developed to describe the health state of the child, whilst then eliciting valuations of those health states from the perspective of the parent/carer. In AADC, the condition typically presents within the first year of life, meaning these challenges are inherent in designing a utility elicitation study. The vignettes were being developed in order to be used in a TTO/SG study and a DCE to derive health state utilities for a CE model. The health states in the model reflect motor and developmental milestones and are based on an ongoing clinical trial investigating gene therapy for AADC deficiency (NCT02926066). The decision was therefore taken to develop the vignettes from parent/carer perspective describing the health of (a hypothetical) child. The five health states were: 1 . the base health state ("bedridden" or untreated AADC deficiency); 2. "head control"; 3. "ability to sit unaided"; 4. "standing with support"; and 5. "walking with assistance" (the "best" health state). An additional vignette was developed in order to capture parental/caregiver quality of life. It should be noted that the economic model, and therefore the health states, reflect severe AADC deficiency. Although a few cases have been reported in the literature where patients have developed the ability to walk independently following gene therapy for AADC deficiency, ${ }^{2}$ these have involved the moderate phenotype. Therefore, the "best" health state in the vignettes was anchored at "walking with assistance".

Development of the vignettes occurred over 5 stages. The vignettes were developed de novo given that no existing vignettes describing AADC deficiency were available in the literature. Caregiver involvement was early on at Stage 2, ahead of the initial vignette development. Early-stage involvement was considered critical to ensure that the project team understood what it is like to live with the condition/have a child live with the condition. This insight then helped to shape the development of the vignettes. Caregivers were 
involved again at Stage 4, reviewing the descriptions alongside clinical experts. Figure 1 provides an overview of the stages.

\section{Ethical Considerations}

No patients were involved in any aspect of the study. Parents and caregivers of patients with AADC deficiency, as well as clinicians involved in the treatment and clinical management of AADC deficiency patients took part. Those parents and caregivers involved in the study (the advisory panel in Stage 2 and survey in Stage 4, described below), as well as the physicians (an advisory panel in Stage 4) were contracted by the study sponsor (PTC Therapeutics) to provide their participation. All participants in Stages 2 and 4 were reimbursed. The stages of the study involving parents and caregivers in the USA (see below) were conducted by the study sponsor and qualify as exempt research (https://www.law.cor nell.edu/cfr/text/45/46.104). Consequently, these were not submitted to an Institutional Review Board or Medical Ethics Review Committee for consideration. The entirety of the study was conducted in compliance with the University of York Code of Practice and Principles for Good Ethical Governance (https://www.

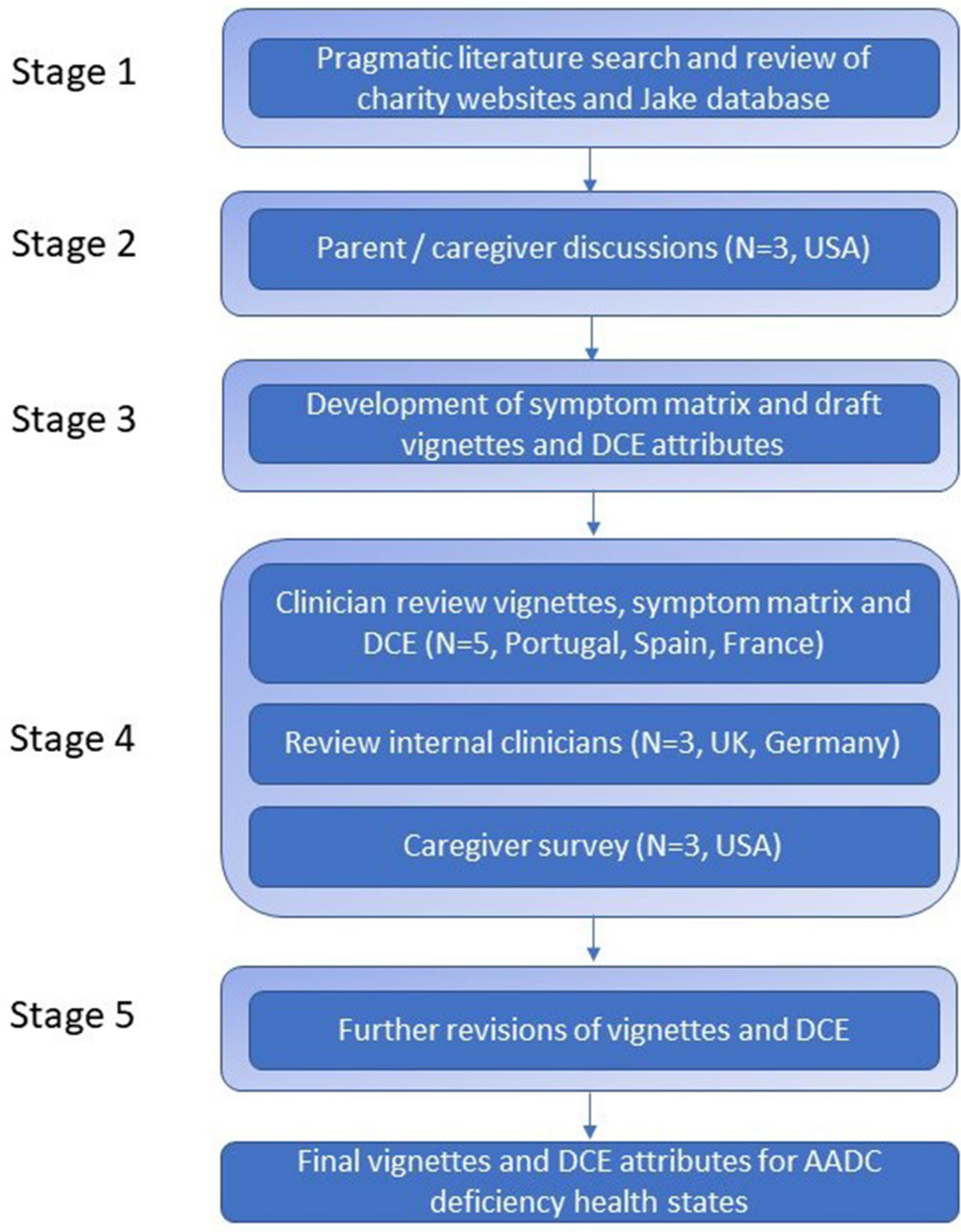

Figure I Overview of the stages. 
york.ac.uk/staff/research/governance/research-policies lethics-code/).

\section{Stages in Vignette Development} Stage I

A pragmatic literature search and review was conducted in PubMed. The key terms used in the search were:

("aromatic L-amino acid decarboxylase" OR “AADC") AND “deficiency” AND (,symptoms,, OR ,signs,,) AND ("paediatric" OR "pediatric").

No limitations were applied in terms of time period or language restrictions. Potential abstracts were downloaded and reviewed to identify full articles. Abstracts were excluded if only reporting: laboratory results or animal studies; other medical conditions; or not reporting the signs and/or symptoms of AADC deficiency. This process was undertaken by a single reviewer (ABS). Stage 1 also included a review of AADC deficiency charity websites (https://www.aadcresearch.org/; https://aadcnews.com/) with the aim of gaining richer insight into what it is like to live with the condition and support a child with the condition. In addition to this, a search was undertaken on the Jake database (http://www.biopku.org/jake/JAKE Details.asp). This is a global repository of anonymised AADC deficiency patients and includes patient data, DNA and laboratory tests, as well as clinical information.

\section{Stage 2}

A structured discussion with caregivers on the challenges and obstacles encountered when caring for a person with AADC deficiency. The structured discussion included a number of themes: the patient journey, patient and family quality of life, patient and caregiver interaction, relationship and communication with the physician/healthcare team, information sources, current treatments/modalities, healthcare insurance, as well as tools, resources and support mechanisms. Three parents/caregivers from in the United States of America provided their insights through a virtual advisory board which lasted a half day.

\section{Stage 3}

Development of a symptom matrix summarising the symptoms and severity of them by health state, drawing on the insight gained from Stages 1 and 2. This was followed by drafting the health state vignettes.

\section{Stage 4}

Clinician review of the symptom matrix and the vignettes, and caregivers' feedback $(\mathrm{N}=3)$ via a bespoke survey. The clinician review consisted of engagement with 3 internal clinicians (including a UK clinician) with expertise in rare diseases, and with 5 external clinicians with expertise specifically in the management of patients with AADC deficiency. The latter took place at an advisory board meeting: 3 of these clinicians were from France, 1 from Portugal and 1 from Spain.

\section{Stage 5}

The vignettes and DCE attributes and levels were revised by the project team based on the feedback received from the clinicians, as well as the parents and caregivers in Stage 4.

\section{Results}

\section{Stages I and 2}

The pragmatic literature review returned 39 potential articles; following a review of the A total of 17 (43.6\%) were excluded: 9 (23.1\%) laboratory/animal studies; 4 other medical conditions (10.3\%); 2 no symptoms reported (5.1\%); and 2 other (5.1\%). The remaining 20 (51.3\%) abstracts were selected for full review (2 English abstracts of Chinese publications were included in addition). The articles have been included as Supplementary Table 1.

There were 81 patients registered on the Jake database: 41 males (51\%), 32 females (40\%) and $8(9 \%)$ where sex had not been recorded. Year of birth ranged from 1973 to 2012. Region of birth was as follows: 20 patients were born in the European Union (25\%, including the UK); 28 in Asia (35\%; Japan (2), Malaysia (6), Singapore (2), Taiwan (18)); 2 patients were born in Israel and 1 in Turkey. There were 30 patients where this had not been recorded. The literature search also revealed an article which had previously summarised the clinical findings in the Jake database ${ }^{7}$ reporting hypotonia in $95 \%$ of cases; $86 \%$ oculogyric crises and $63 \%$ developmental retardation. The symptoms and broader impact of AADC deficiency identified during Stages 1 and 2 are summarised in Table 1. Stage 1 has been split into "AADC charity website" versus "literature" identified symptoms and impacts.

There was high consensus across the 3 sources in terms of the key symptoms and signs, however, there were 4 key differences. First, the literature reviewed did not cover the volume and burden of the medication regimen nor the amount of time patients and their caregivers spend in hospital, compared to the supported websites and caregivers' discussion. Second, whilst the charity websites identified issues relating to cognitive functioning, namely inability speak and, conversely, capabilities around making eye 
Table I Summary of Stages I and 2

\begin{tabular}{|c|c|c|c|}
\hline Domain & Stage I Literature & Stage I Charity Websites & Stage 2 Carers' Discussion \\
\hline Neuromuscular & $\begin{array}{l}\text { Hypotonia } \\
\text { Oculogyric crises } \\
\text { Dystonia } \\
\text { Hypokinesia/motor impairment }\end{array}$ & $\begin{array}{l}\text { Hypotonia, (eg, "low muscle tone") } \\
\text { Oculogyric crises } \\
\text { Dystonia (eg, "muscle spasms") } \\
\text { Inability to sit up/stand/walk }\end{array}$ & $\begin{array}{l}\text { Hypotonia (“muscle tone abnormalities") } \\
\text { Oculogyric crises } \\
\text { Dystonia (eg, twisted body syndrome/ } \\
\text { seizures) } \\
\text { - }\end{array}$ \\
\hline Cognition & $\begin{array}{l}\text { Developmental delay } \\
- \\
- \\
-\end{array}$ & $\begin{array}{l}\text { Developmental delay } \\
\text { No voice, not able to speak } \\
\text { Can make eye contact } \\
\text { Can respond with expressions }\end{array}$ & $\begin{array}{l}\text { Developmental delay (“lack milestone } \\
\text { development"/'no milestones') } \\
\text { - } \\
\text { - } \\
\text { - }\end{array}$ \\
\hline Care & $\begin{array}{l}- \\
-\end{array}$ & $\begin{array}{l}\text { Lots of medications } \\
\text { Time spent in hospital }\end{array}$ & $\begin{array}{l}\text { Lots of medications } \\
\text { Time spent in hospital }\end{array}$ \\
\hline Autonomic & $\begin{array}{l}\text { Ptosis } \\
\text { Excess sweating } \\
\text { Nasal congestion } \\
\text { Gastrointestinal problems (reflux, } \\
\text { diarrhoea, constipation) } \\
\text { Hypoglycaemia } \\
\text { Excess saliva }\end{array}$ & $\begin{array}{l}- \\
- \\
- \\
\text { Severe gut dysmotility, reflux, excess } \\
\text { saliva, need for feeding tube } \\
\text { - } \\
\text { - }\end{array}$ & $\begin{array}{l}\text { Excess sweating } \\
- \\
\text { Inability to feed oneself, vomiting } \\
\text { Hypoglycaemia } \\
\text { Excess saliva ("drooling") }\end{array}$ \\
\hline Behavioural & $\begin{array}{l}\text { Irritability } \\
\text { Excess crying/dysphoria } \\
\text { Sleep disturbance }\end{array}$ & $\begin{array}{l}- \\
- \\
-\end{array}$ & $\begin{array}{l}- \\
- \\
\text { Insomnia }\end{array}$ \\
\hline $\begin{array}{l}\text { Respiratory } \\
\text { Other }\end{array}$ & $\begin{array}{l}- \\
-\end{array}$ & $\begin{array}{l}- \\
- \\
-\end{array}$ & $\begin{array}{l}\text { Difficulty breathing } \\
\text { Neutropenia (autoimmune) } \\
\text { Impact on siblings, family quality of life, } \\
\text { financial }\end{array}$ \\
\hline
\end{tabular}

contact and responding with expressions, the carers discussion and the literature referred more broadly to "developmental delay". Third, autonomic symptoms were covered in the literature, but were referred to less by carers, particularly the charity websites which mentioned only gastrointestinal problems. Finally, whilst the literature highlighted several behavioural issues, this was not the focus of carers and the charity websites. Here, the focus was more on broader impact, including on family quality of life and finances.

\section{Stage 3}

The symptoms of AADC deficiency identified at Stages 1 and 2 were grouped into neuromuscular $(\mathrm{N}=4)$, behavioural $(\mathrm{N}=3)$ and cognitive $(\mathrm{N}=1)$, alongside 3 functional impairments. These are summarised in Table 2 .

Table 3 summarises the descriptions used in the draft vignettes, broken down by each of the symptom and functioning domains. As can be seen, certain symptom descriptions do not change/improve through each and every health state (i.e., from the worst to the best health state). Notably, the same description/severity is used for

Table 2 Domains and Symptoms Identified in Stages I and 2

\begin{tabular}{|l|l|}
\hline Domain & Symptom \\
\hline Neuromuscular & $\begin{array}{l}\text { Hypotonia } \\
\text { Oculogyric crises } \\
\text { Motor impairment } \\
\text { Dystonia }\end{array}$ \\
\hline Functional & $\begin{array}{l}\text { Feeding and swallowing difficulties } \\
\text { Autonomous feeding } \\
\text { Weight gain }\end{array}$ \\
\hline Cognitive & $\begin{array}{l}\text { Mental impairment (delayed cognitive } \\
\text { development) }\end{array}$ \\
\hline Behavioural & $\begin{array}{l}\text { Irritability } \\
\text { Screaming ("crying child") } \\
\text { Sleep }\end{array}$ \\
\hline
\end{tabular}


Table 3 Initial Vignettes

\begin{tabular}{|c|c|c|c|c|c|}
\hline Domain & Baseline Vignette & Head Control & $\begin{array}{l}\text { Ability to Sit } \\
\text { Unaided }\end{array}$ & $\begin{array}{l}\text { Standing with } \\
\text { Support }\end{array}$ & $\begin{array}{l}\text { Walking with } \\
\text { Assistance }\end{array}$ \\
\hline Hypotonia & $\begin{array}{l}\text { They have very poorly } \\
\text { developed muscle tone } \\
\text { meaning their body, } \\
\text { arms and legs are very } \\
\text { floppy. This means } \\
\text { your child is unable to } \\
\text { grasps or hold onto } \\
\text { things. }\end{array}$ & $\begin{array}{l}\text { They have very poorly } \\
\text { developed muscle tone } \\
\text { meaning their body, } \\
\text { arms and legs are very } \\
\text { floppy. This means } \\
\text { your child is unable to } \\
\text { grasp or hold onto } \\
\text { things. }\end{array}$ & $\begin{array}{l}\text { The muscles in their } \\
\text { body, arms and legs are } \\
\text { still floppy. Your child is } \\
\text { able to reach out and } \\
\text { or hold onto things. }\end{array}$ & $\begin{array}{l}\text { The muscles in their } \\
\text { body, arms and legs are } \\
\text { still a bit floppy. Your } \\
\text { child can reach out } \\
\text { their hands and or hold } \\
\text { onto things. }\end{array}$ & $\begin{array}{l}\text { The muscles in their } \\
\text { body, arms and legs are } \\
\text { still a bit floppy, but } \\
\text { your child can reach } \\
\text { out their hands and or } \\
\text { hold onto things. }\end{array}$ \\
\hline $\begin{array}{l}\text { Oculogyric } \\
\text { crises }\end{array}$ & $\begin{array}{l}\text { Your child experiences } \\
\text { something called an } \\
\text { "oculogyric crisis". } \\
\text { This is where their } \\
\text { eyes rotate or roll in } \\
\text { unusual ways, again this } \\
\text { is something that } \\
\text { happens involuntarily } \\
\text { and is not controlled } \\
\text { by your child. }\end{array}$ & $\begin{array}{l}\text { Your child experiences } \\
\text { something called an } \\
\text { "oculogyric crisis". } \\
\text { This is where their } \\
\text { eyes rotate or roll in } \\
\text { unusual ways, again this } \\
\text { is something that } \\
\text { happens involuntarily } \\
\text { and is not controlled } \\
\text { by your child. }\end{array}$ & $\begin{array}{l}\text { Your child experiences } \\
\text { something called an } \\
\text { "oculogyric crisis". } \\
\text { This is where their } \\
\text { eyes rotate or roll in } \\
\text { unusual ways, again this } \\
\text { is something that } \\
\text { happens involuntarily } \\
\text { and is not controlled } \\
\text { by your child. This } \\
\text { happens occasionally. }\end{array}$ & $\begin{array}{l}\text { Your child experiences } \\
\text { something called an } \\
\text { "oculogyric crisis". } \\
\text { This is where their } \\
\text { eyes rotate or roll in } \\
\text { unusual ways, again this } \\
\text { is something that } \\
\text { happens involuntarily } \\
\text { and is not controlled } \\
\text { by your child. This } \\
\text { happens very } \\
\text { occasionally. }\end{array}$ & \\
\hline $\begin{array}{l}\text { Motor } \\
\text { impairment }\end{array}$ & $\begin{array}{l}\text { Your child in bedridden } \\
\text { and unable to move by } \\
\text { themselves. This means } \\
\text { that your child is } \\
\text { unable to lift and } \\
\text { control their head, } \\
\text { crawl, sit, or stand. }\end{array}$ & $\begin{array}{l}\text { Your child is bedridden } \\
\text { and unable to move by } \\
\text { themselves. This means } \\
\text { that your child is } \\
\text { unable to crawl, sit, or } \\
\text { stand. However, your } \\
\text { child is able to control } \\
\text { their head. }\end{array}$ & $\begin{array}{l}\text { Your child is not } \\
\text { bedridden and able to } \\
\text { move by themselves } \\
\text { voluntarily. Your child } \\
\text { can sit without help, } \\
\text { although they are not } \\
\text { able to crawl or stand. } \\
\text { Your child can control } \\
\text { their head. }\end{array}$ & $\begin{array}{l}\text { Your child is not } \\
\text { bedridden and can } \\
\text { move by themselves } \\
\text { voluntarily. Your child } \\
\text { can sit without help } \\
\text { and stand with support } \\
\text { from a walking frame } \\
\text { or another person. }\end{array}$ & $\begin{array}{l}\text { Your child is not } \\
\text { bedridden and is able } \\
\text { to move by themselves. } \\
\text { Your child can lift and } \\
\text { control his or her head } \\
\text { and is able to sit } \\
\text { without assistance. } \\
\text { They can stand without } \\
\text { any help, and walk as } \\
\text { well, although your } \\
\text { child needs support } \\
\text { from a walking frame } \\
\text { or person to do so. }\end{array}$ \\
\hline Dystonia & $\begin{array}{l}\text { Your child will also } \\
\text { experience painful } \\
\text { muscle spasms, and } \\
\text { their arms and legs may } \\
\text { move involuntarily with } \\
\text { sudden jerking or } \\
\text { twisting. }\end{array}$ & $\begin{array}{l}\text { Your child will also } \\
\text { experience painful } \\
\text { muscle spasms, and } \\
\text { their arms and legs may } \\
\text { move involuntarily with } \\
\text { sudden jerking or } \\
\text { twisting. }\end{array}$ & $\begin{array}{l}\text { Your child will also } \\
\text { occasionally } \\
\text { experience painful } \\
\text { muscle spasms, and } \\
\text { their arms and legs may } \\
\text { still move involuntarily } \\
\text { with sudden jerking or } \\
\text { twisting. }\end{array}$ & $\begin{array}{l}\text { Your child will also } \\
\text { very occasionally } \\
\text { experience painful } \\
\text { muscle spasms, and } \\
\text { their arms and legs may } \\
\text { sometimes move } \\
\text { involuntarily with } \\
\text { sudden jerking or } \\
\text { twisting. }\end{array}$ & \\
\hline $\begin{array}{l}\text { Feeding } \\
\text { and } \\
\text { swallowing } \\
\text { difficulties }\end{array}$ & $\begin{array}{l}\text { They are unable to } \\
\text { feed themselves and } \\
\text { may need to be fed } \\
\text { through a tube (a } \\
\text { "naso-gastric" tube). }\end{array}$ & $\begin{array}{l}\text { They are unable to } \\
\text { feed themselves and } \\
\text { may need to be fed } \\
\text { through a tube (a } \\
\text { "naso-gastric" tube). }\end{array}$ & $\begin{array}{l}\text { They are able to feed } \\
\text { themselves a little bit, } \\
\text { and do not need to be } \\
\text { fed through a tube (a } \\
\text { "naso-gastric" tube). }\end{array}$ & $\begin{array}{l}\text { They are able to feed } \\
\text { themselves. }\end{array}$ & $\begin{array}{l}\text { They are able to feed } \\
\text { themselves }\end{array}$ \\
\hline
\end{tabular}

(Continued) 
Table 3 (Continued).

\begin{tabular}{|c|c|c|c|c|c|}
\hline Domain & Baseline Vignette & Head Control & $\begin{array}{l}\text { Ability to Sit } \\
\text { Unaided }\end{array}$ & $\begin{array}{l}\text { Standing with } \\
\text { Support }\end{array}$ & $\begin{array}{l}\text { Walking with } \\
\text { Assistance }\end{array}$ \\
\hline $\begin{array}{l}\text { Weight } \\
\text { gain }\end{array}$ & $\begin{array}{l}\text { Your child is very } \\
\text { underweight }\end{array}$ & $\begin{array}{l}\text { Your child is } \\
\text { underweight }\end{array}$ & $\begin{array}{l}\text { Your child is slightly } \\
\text { underweight. }\end{array}$ & $\begin{array}{l}\text { Your child's weight will } \\
\text { be similar to that of } \\
\text { a child their own age. }\end{array}$ & $\begin{array}{l}\text { Their body weight is } \\
\text { the same as that of } \\
\text { a child their own age }\end{array}$ \\
\hline $\begin{array}{l}\text { Mental } \\
\text { impairment }\end{array}$ & $\begin{array}{l}\text { Your child is able to } \\
\text { follow objects with their } \\
\text { eyes and recognise and } \\
\text { smile at people. They } \\
\text { can understand simple } \\
\text { words but are not able } \\
\text { to speak. }\end{array}$ & $\begin{array}{l}\text { Your child is able to } \\
\text { follow objects with their } \\
\text { eyes and recognise and } \\
\text { smile at people. They } \\
\text { can understand simple } \\
\text { words but are not able } \\
\text { to speak. }\end{array}$ & $\begin{array}{l}\text { Your child is able to } \\
\text { follow objects with their } \\
\text { eyes and recognise and } \\
\text { smile at people. They } \\
\text { can understand simple } \\
\text { words and babble a little. }\end{array}$ & $\begin{array}{l}\text { They can understand } \\
\text { simple words and are } \\
\text { able to say a few } \\
\text { words. }\end{array}$ & $\begin{array}{l}\text { They can understand } \\
\text { sentences and can speak } \\
\text { and hold conversation. } \\
\text { Your child meets the } \\
\text { same development } \\
\text { milestones as other } \\
\text { children of the same age. }\end{array}$ \\
\hline $\begin{array}{l}\text { Irritabilityl } \\
\text { screaming } \\
\text { child }\end{array}$ & $\begin{array}{l}\text { Your child screams } \\
\text { constantly throughout } \\
\text { the day and night. } \\
\text { They will be irritable } \\
\text { and agitated. }\end{array}$ & $\begin{array}{l}\text { Your child screams } \\
\text { frequently throughout } \\
\text { the day and night. } \\
\text { They will be irritable } \\
\text { and agitated. }\end{array}$ & $\begin{array}{l}\text { Your child screams } \\
\text { occasionally } \\
\text { throughout the day and } \\
\text { night. } \\
\text { They may occasionally } \\
\text { become irritable and } \\
\text { agitated. }\end{array}$ & $\begin{array}{l}\text { They may very } \\
\text { occasionally become } \\
\text { irritable and agitated }\end{array}$ & $\begin{array}{l}\text { Their body weight is the } \\
\text { same as that of a child } \\
\text { their own age, as is their } \\
\text { mood, which means } \\
\text { that they may } \\
\text { occasionally cry, but in } \\
\text { appropriate situations. }\end{array}$ \\
\hline Sleep & $\begin{array}{l}\text { Your child will have } \\
\text { problems sleeping, as } \\
\text { well as having } \\
\text { disturbed sleep. }\end{array}$ & $\begin{array}{l}\text { Your child will have } \\
\text { problems sleeping, as } \\
\text { well as having } \\
\text { disturbed sleep }\end{array}$ & $\begin{array}{l}\text { Your child may have } \\
\text { problems sleeping, but } \\
\text { will sleep for periods of } \\
\text { time. }\end{array}$ & $\begin{array}{l}\text { Your child's will sleep } \\
\text { will hardly be affected. }\end{array}$ & $\begin{array}{l}\text { Their sleep will not be } \\
\text { affected. }\end{array}$ \\
\hline
\end{tabular}

Note: Italicised text refers to text amended from the previous stage.

the baseline and head control health states for several symptoms: hypotonia, oculogyric crises, dystonia, feeding and swallowing difficulties, irritability and sleeping. Clinical experts and caregivers were asked to feedback on the accuracy of this at Stage 4.

\section{Stage 4}

\section{Clinician Feedback}

Clinician feedback focussed on additional symptoms across each of the health states that were felt to be important to include and on the severity of symptoms described across the health states. The additional symptoms suggested by clinicians were: hypoglycaemia (for some patients, with this flagged as a route to diagnosis) and autonomic symptoms including nasal congestion, drooling and gastrointestinal issues. These had all been identified at Stage 1 and Stage 2 but had been excluded from the draft vignettes due to the number of symptoms to cover. Clinicians fed back that AADC deficiency is idiopathic, varying from case to case and that symptoms do not necessarily improve at the same rate and across each and every health state. This was reflected already in the health state descriptions. Example clinician quotations include:

"Description of patients is very difficult as it may change from one case to another, severity of the disease varies between countries".

And

"As an example, patient can improve in motor milestones but still may not be able to swallow properly, different symptoms (like oculogyric crises) may or may not improve in correlation with motor milestone, different symptoms may improve at different rates".

Nevertheless, the literature ${ }^{2}$ suggested that although milestones may be reached at different rates, improvement in symptoms did occur in a global way. Severity of the symptoms was therefore varied across the 5 vignettes so that symptoms decreased globally in severity moving from the bedridden to the walking health state.

The additional feedback on the vignettes only suggested the inclusion of hypoglycaemia and autonomic symptoms, rather than conflicting suggestions/feedback. 
Clinicians also emphasised the impact of oculogyric crises on quality of life, suggesting greater emphasis on this would be justified in the health state descriptions.

\section{Caregiver Feedback}

The caregiver feedback similar highlighted the idiopathic nature of AADC, with additional symptoms of mouth dislocation, use of a ventilator and daily vomiting suggested. None of these symptoms had been identified at Stages 1 or 2 nor by the clinicians. A caregiver with a child whom they self-rated as fitting the "walking with assistance" health state also fed back that their child does not meet some developmental milestones, that they are behind peers academically and still have problems sleeping, causing tiredness during the day. This indicated the need to revise the "best" health state vignette to reflect these impairments.

\section{Stage 5}

The vignettes were revised to arrive at the final versions for use in a TTO and SG study. The revisions focused on: adding in autonomic symptoms (abdominal problems and nasal congestion) raised by clinicians, mental impairment/ developmental milestones raised by caregivers, and rephrasing the oculogyric crisis statements for greater emphasis and clarity. Some suggested revisions were not made. These were those considered to be very idiopathic: e.g., single caregiver statements regarding symptoms such as vomiting. An additional vignette was created to capture the impact of AADC deficiency on parents and caregivers. This vignette described the burden of care, such as round the clock supervision of a child with AADC deficiency, close supervision of medication, sleep disruption, the inability to go out the house very often (or only for short periods of time) and loss of work due to the care process and frequent hospital visits.

Table 4 summarises the changes made to the descriptions summarised in Table 3, based on the feedback received.

\section{Discussion}

Utilities are an important part of economic modelling. Robustly capturing what it is like to live with a particular disease benefits from patient and/or caregiver engagement. For rare diseases such as AADC deficiency, utility elicitation via direct methods is often more typical due to the lack of published utilities and difficulties with using generic preference-based measures (GPBMS) in clinical trials. Nonetheless, direct utility elicitation can still be challenging due to the small number of patients with the disease, which can make patient engagement more difficult, combined with the fact that patients will often be children. In this study, a 5 -stage strategy was used to produce vignettes describing 5 different AADC deficiency health states aligned to the primary outcomes in a clinical trial for subsequent use in economic modelling. The emphasis was on early engagement with caregivers, but vignette development also drew on insight gained from published literature, charity websites and clinical expert review.

Each stakeholder/source (caregiver, charity, clinical experts, the literature) contributed to the final vignettes. The differences in the symptoms and functioning limitations highlighted, with caregivers focussing less on autonomic symptoms and behavioural issues than the literature reviewed, and the literature focusing less on the burden of medication and hospital treatment, demonstrate the importance of drawing upon multiple stakeholders and sources. This may be especially important for rare diseases where there are fewer patients and clinical experts to engage with. To some extent, adopting this approach requires some degree of triangulation of evidence, to avoid focusing on very individualistic things that may only be reported by a single clinician or caregiver, whilst still benefiting from the input of each person engaged with. In this study, we have done this triangulation through providing a clear break down of the findings at each stage, and the impact upon the vignettes. For example, at Stage 5, when revising the vignettes for the final time, single symptoms flagged by caregivers at Stage 4 for the first time, having not been picked up in the literature nor in the charity websites nor clinical expert reviews were not included in the revisions. These were difficult decisions to make. These singularly mentioned symptoms may reflect the idiopathic nature of the disease and treatment response reported by the clinical experts, which posed a particular challenge for vignette development. Nonetheless, overall, the feedback from clinicians was consistent, flagging autonomic symptoms and hypoglycaemia, and the feedback from caregivers highlighted additional symptoms to consider, rather than inaccuracies in the descriptions themselves. This provides reassurance that the health states capture what it is like to live with AADC deficiency, despite the idiopathic nature of it, and supports the assertion of Kojima et al. ${ }^{2}$ that global improvements can be seen in AADC deficiency. 
Table 4 Final Vignettes

\begin{tabular}{|c|c|c|c|c|c|}
\hline Domain & Baseline Vignette & Head Control & $\begin{array}{l}\text { Ability to Sit } \\
\text { Unaided }\end{array}$ & $\begin{array}{l}\text { Standing with } \\
\text { Support }\end{array}$ & $\begin{array}{l}\text { Walking with } \\
\text { Assistance }\end{array}$ \\
\hline Hypotonia & $\begin{array}{l}\text { They have very poorly } \\
\text { developed muscle tone } \\
\text { meaning their body, } \\
\text { arms and legs are very } \\
\text { floppy. This means } \\
\text { your child is unable to } \\
\text { grasps or hold onto } \\
\text { things. }\end{array}$ & $\begin{array}{l}\text { They have very poorly } \\
\text { developed muscle tone } \\
\text { meaning their body, } \\
\text { arms and legs are very } \\
\text { floppy. This means } \\
\text { your child is unable to } \\
\text { grasp or hold onto } \\
\text { things. }\end{array}$ & $\begin{array}{l}\text { The muscles in their } \\
\text { body, arms and legs are } \\
\text { still floppy. Your child is } \\
\text { able to reach out and } \\
\text { or hold onto things. }\end{array}$ & $\begin{array}{l}\text { The muscles in their } \\
\text { body, arms and legs are } \\
\text { still a bit floppy. Your } \\
\text { child can reach out } \\
\text { their hands and or } \\
\text { hold onto things. }\end{array}$ & $\begin{array}{l}\text { The muscles in their } \\
\text { body, arms and legs are } \\
\text { still a bit floppy, but } \\
\text { your child can reach } \\
\text { out their hands and or } \\
\text { hold onto things. } \\
\text { The muscle in their body, } \\
\text { arms and legs are still } \\
\text { a bit limper than normal, } \\
\text { but your child can reach } \\
\text { out and or hold onto } \\
\text { things }\end{array}$ \\
\hline $\begin{array}{l}\text { Oculogyric } \\
\text { crises }\end{array}$ & $\begin{array}{l}\text { Your child experiences } \\
\text { something called an } \\
\text { "oculogyric crisis". } \\
\text { This is where their } \\
\text { eyes rotate or roll in } \\
\text { unusual ways, again this } \\
\text { is something that } \\
\text { happens involuntarily } \\
\text { and is not controlled } \\
\text { by your child. } \\
\text { Your child experiences } \\
\text { something called an } \\
\text { oculogyric crisis. This is } \\
\text { where their eyes rotate } \\
\text { or roll in unusual ways, } \\
\text { similar to an epileptic } \\
\text { seizure. This may last for } \\
\text { several hours, several } \\
\text { times a day. }\end{array}$ & $\begin{array}{l}\text { Your child experiences } \\
\text { something called an } \\
\text { "oculogyric crisis". } \\
\text { This is where their } \\
\text { eyes rotate or roll in } \\
\text { unusual ways, again this } \\
\text { is something that } \\
\text { happens involuntarily } \\
\text { and is not controlled } \\
\text { by your child. } \\
\text { Your child experiences } \\
\text { something called an } \\
\text { oculogyric crisis. This is } \\
\text { where their eyes rotate } \\
\text { or roll in unusual ways, } \\
\text { similar to an epileptic } \\
\text { seizure. These may last } \\
\text { for around an hour, } \\
\text { several times a day. }\end{array}$ & $\begin{array}{l}\text { Your child experiences } \\
\text { something called an } \\
\text { "oculogyric crisis". } \\
\text { This is where their } \\
\text { eyes rotate or roll in } \\
\text { unusual ways, again this } \\
\text { is something that } \\
\text { happens involuntarily } \\
\text { and is not controlled } \\
\text { by your child. This } \\
\text { happens occasionally. }\end{array}$ & $\begin{array}{l}\text { Your child experiences } \\
\text { something called an } \\
\text { "oculogyric crisis". } \\
\text { This is where their } \\
\text { eyes rotate or roll in } \\
\text { unusual ways, again this } \\
\text { is something that } \\
\text { happens involuntarily } \\
\text { and is not controlled } \\
\text { by your child. This } \\
\text { happens very } \\
\text { occasionally. }\end{array}$ & \\
\hline $\begin{array}{l}\text { Motor } \\
\text { impairment }\end{array}$ & $\begin{array}{l}\text { Your child in bedridden } \\
\text { and unable to move by } \\
\text { themselves. This } \\
\text { means that your child } \\
\text { is unable to lift and } \\
\text { control their head, } \\
\text { crawl, sit, or stand. }\end{array}$ & $\begin{array}{l}\text { Your child is bedridden } \\
\text { and unable to move by } \\
\text { themselves. This } \\
\text { means that your child } \\
\text { is unable to crawl, sit, } \\
\text { or stand. However, } \\
\text { your child is able to } \\
\text { control their head. }\end{array}$ & $\begin{array}{l}\text { Your child is not } \\
\text { bedridden and able to } \\
\text { move by themselves } \\
\text { voluntarily. Your child } \\
\text { can sit without help, } \\
\text { although they are not } \\
\text { able to crawl or stand. } \\
\text { Your child can control } \\
\text { their head. }\end{array}$ & $\begin{array}{l}\text { Your child is not } \\
\text { bedridden and can } \\
\text { move by themselves } \\
\text { voluntarily. Your child } \\
\text { can sit without help } \\
\text { and stand with support } \\
\text { from a walking frame } \\
\text { or another person. }\end{array}$ & $\begin{array}{l}\text { Your child is not } \\
\text { bedridden and is able } \\
\text { to move by } \\
\text { themselves. Your child } \\
\text { can lift and control his } \\
\text { or her head and is able } \\
\text { to sit without } \\
\text { assistance. They can } \\
\text { stand without any help, } \\
\text { and walk as well, } \\
\text { although your child } \\
\text { needs support from } \\
\text { a walking frame or } \\
\text { person to do so. }\end{array}$ \\
\hline
\end{tabular}

(Continued) 
Table 4 (Continued).

\begin{tabular}{|c|c|c|c|c|c|}
\hline Domain & Baseline Vignette & Head Control & $\begin{array}{l}\text { Ability to Sit } \\
\text { Unaided }\end{array}$ & $\begin{array}{l}\text { Standing with } \\
\text { Support }\end{array}$ & $\begin{array}{l}\text { Walking with } \\
\text { Assistance }\end{array}$ \\
\hline Dystonia & $\begin{array}{l}\text { Your child will also } \\
\text { frequently experience } \\
\text { painful muscle spasms, } \\
\text { and their arms and legs } \\
\text { may move involuntarily } \\
\text { with sudden jerking or } \\
\text { twisting. }\end{array}$ & $\begin{array}{l}\text { Your child will also } \\
\text { often experience } \\
\text { painful muscle spasms, } \\
\text { and their arms and legs } \\
\text { may move involuntarily } \\
\text { with sudden jerking or } \\
\text { twisting. }\end{array}$ & $\begin{array}{l}\text { Your child will also } \\
\text { occasionally } \\
\text { experience painful } \\
\text { muscle spasms, and } \\
\text { their arms and legs } \\
\text { may still move } \\
\text { involuntarily with } \\
\text { sudden jerking or } \\
\text { twisting. }\end{array}$ & $\begin{array}{l}\text { Your child will also } \\
\text { very occasionally } \\
\text { experience painful } \\
\text { muscle spasms, and } \\
\text { their arms and legs } \\
\text { may sometimes move } \\
\text { involuntarily with } \\
\text { sudden jerking or } \\
\text { twisting. }\end{array}$ & \\
\hline $\begin{array}{l}\text { Feeding and } \\
\text { swallowing } \\
\text { difficulties }\end{array}$ & $\begin{array}{l}\text { They are unable to } \\
\text { feed themselves and } \\
\text { may need to be fed } \\
\text { through a tube (a } \\
\text { "naso-gastric" tube). }\end{array}$ & $\begin{array}{l}\text { They are unable to } \\
\text { feed themselves and } \\
\text { may need to be fed } \\
\text { through a tube (a } \\
\text { "naso-gastric" tube). }\end{array}$ & $\begin{array}{l}\text { They are able to feed } \\
\text { themselves a little bit, } \\
\text { and do not need to be } \\
\text { fed through a tube (a } \\
\text { "naso-gastric" tube). }\end{array}$ & $\begin{array}{l}\text { They are able to feed } \\
\text { themselves. } \\
\text { They are able to feed } \\
\text { themselves more or less } \\
\text { on their own }\end{array}$ & $\begin{array}{l}\text { They are able to feed } \\
\text { themselves }\end{array}$ \\
\hline $\begin{array}{l}\text { Weight } \\
\text { gain (removed } \\
\text { in final version) }\end{array}$ & $\begin{array}{l}\text { Your child is very } \\
\text { underweight (removed } \\
\text { in final version) }\end{array}$ & $\begin{array}{l}\text { Your child is } \\
\text { underweight (removed } \\
\text { in final version) }\end{array}$ & $\begin{array}{l}\text { Your child is slightly } \\
\text { underweight. (removed } \\
\text { in final version) }\end{array}$ & $\begin{array}{l}\text { Your child's weight will } \\
\text { be similar to that of } \\
\text { a child their own age. } \\
\text { (removed in final version) }\end{array}$ & $\begin{array}{l}\text { Their body weight is } \\
\text { the same as that of } \\
\text { a child their own age }\end{array}$ \\
\hline $\begin{array}{l}\text { Mental } \\
\text { impairment }\end{array}$ & $\begin{array}{l}\text { Your child is able to } \\
\text { follow objects with } \\
\text { their eyes and } \\
\text { recognise and smile at } \\
\text { people. They can } \\
\text { understand simple } \\
\text { words but are not able } \\
\text { to speak. } \\
\text { Your child is unable to } \\
\text { follow objects with their } \\
\text { eyes and unable to } \\
\text { recognise and interact } \\
\text { with people. They can } \\
\text { understand simple words } \\
\text { but are not able to } \\
\text { speak. }\end{array}$ & $\begin{array}{l}\text { Your child is able to } \\
\text { follow objects with } \\
\text { their eyes and } \\
\text { recognise and smile at } \\
\text { people. They can } \\
\text { understand simple } \\
\text { words but are not able } \\
\text { to speak. } \\
\text { Your child is able to } \\
\text { follow objects with their } \\
\text { eyes and recognise and } \\
\text { smile at people. They } \\
\text { can understand simple } \\
\text { words but are not able to } \\
\text { speak. }\end{array}$ & $\begin{array}{l}\text { Your child is able to } \\
\text { follow objects with } \\
\text { their eyes and } \\
\text { recognise and smile at } \\
\text { people. They can } \\
\text { understand simple } \\
\text { words and babble } \\
\text { a little. } \\
\text { Your child is able to } \\
\text { follow objects with their } \\
\text { eyes and recognise and } \\
\text { smile at people. They } \\
\text { can understand simple } \\
\text { words and babble a little. }\end{array}$ & $\begin{array}{l}\text { They can understand } \\
\text { simple words and are } \\
\text { able to say a few } \\
\text { words. } \\
\text { Your child is able to } \\
\text { follow objects with their } \\
\text { eyes and recognise and } \\
\text { smile at people. They } \\
\text { can understand simple } \\
\text { words and are able to } \\
\text { say a few words. }\end{array}$ & $\begin{array}{l}\text { They can understand } \\
\text { sentences and can } \\
\text { speak and hold } \\
\text { conversation. Your } \\
\text { child meets the same } \\
\text { development } \\
\text { milestones as other } \\
\text { children of the same } \\
\text { age. } \\
\text { They can understand } \\
\text { simple sentences and } \\
\text { can speak a little. Your } \\
\text { child meets some } \\
\text { developmental } \\
\text { milestones as other } \\
\text { children of the same age }\end{array}$ \\
\hline $\begin{array}{l}\text { Irritabilityl } \\
\text { screaming } \\
\text { child }\end{array}$ & $\begin{array}{l}\text { Your child screams } \\
\text { constantly throughout } \\
\text { the day and night. } \\
\text { They will be extremely } \\
\text { irritable and agitated. }\end{array}$ & $\begin{array}{l}\text { Your child screams } \\
\text { frequently throughout } \\
\text { the day and night. } \\
\text { They will be very } \\
\text { irritable and agitated. }\end{array}$ & $\begin{array}{l}\text { Your child screams } \\
\text { occasionally throughout } \\
\text { the day and night. } \\
\text { They may occasionally } \\
\text { become irritable and } \\
\text { agitated. }\end{array}$ & $\begin{array}{l}\text { Your child may still cry } \\
\text { They may very } \\
\text { occasionally become } \\
\text { irritable and agitated }\end{array}$ & $\begin{array}{l}\text { Their body weight is } \\
\text { the same as that of } \\
\text { a child their own age, } \\
\text { as is their mood, which } \\
\text { means that they may } \\
\text { occasionally cry, but in } \\
\text { appropriate situations. }\end{array}$ \\
\hline Sleep & $\begin{array}{l}\text { Your child will have } \\
\text { problems sleeping, as } \\
\text { well as having } \\
\text { disturbed sleep. } \\
\text { Your child will have } \\
\text { problems sleeping. }\end{array}$ & $\begin{array}{l}\text { Your child will have } \\
\text { problems sleeping, as } \\
\text { well as having } \\
\text { disturbed sleep } \\
\text { Your child will have } \\
\text { problems sleeping. }\end{array}$ & $\begin{array}{l}\text { Your child may have } \\
\text { problems sleeping, but } \\
\text { will sleep for periods } \\
\text { of time. }\end{array}$ & $\begin{array}{l}\text { Your child's will sleep } \\
\text { will hardly be affected. } \\
\text { Your child will sleep } \\
\text { more than usual }\end{array}$ & $\begin{array}{l}\text { Their sleep will not be } \\
\text { affected. } \\
\text { Your child will be more } \\
\text { tired than usual }\end{array}$ \\
\hline
\end{tabular}

(Continued) 
Table 4 (Continued).

\begin{tabular}{|c|c|c|c|c|c|}
\hline Domain & Baseline Vignette & Head Control & $\begin{array}{l}\text { Ability to Sit } \\
\text { Unaided }\end{array}$ & $\begin{array}{l}\text { Standing with } \\
\text { Support }\end{array}$ & $\begin{array}{l}\text { Walking with } \\
\text { Assistance }\end{array}$ \\
\hline Autonomic & $\begin{array}{l}\text { Your child will have } \\
\text { severe abdominal } \\
\text { problems, such as } \\
\text { constipation or diarrhoea } \\
\text { Other symptoms include } \\
\text { severely blocked nose } \\
\text { (nasal congestion), which } \\
\text { may lead to serious } \\
\text { chest infections, as well } \\
\text { as excessive drooling, } \\
\text { excessive sweating and } \\
\text { extreme tiredness }\end{array}$ & $\begin{array}{l}\text { Your child will have } \\
\text { abdominal problems, } \\
\text { such as constipation or } \\
\text { diarrhoea } \\
\text { Other symptoms include } \\
\text { a blocked nose (nasal } \\
\text { congestion), which may } \\
\text { lead to chest infections, } \\
\text { as well as frequent } \\
\text { drooling, frequent } \\
\text { sweating and tiredness }\end{array}$ & $\begin{array}{l}\text { Your child will have } \\
\text { occasional abdominal } \\
\text { problems, such as } \\
\text { constipation or diarrhoea } \\
\text { Other symptoms include } \\
\text { the occasional blocked } \\
\text { nose (nasal congestion) } \\
\text { as well as some drooling } \\
\text { and sweating }\end{array}$ & $\begin{array}{l}\text { Other symptoms include } \\
\text { the occasional blocked } \\
\text { nose (nasal congestion) } \\
\text { as well as some } \\
\text { occasional drooling and } \\
\text { sweating }\end{array}$ & \\
\hline
\end{tabular}

Notes: Italicised text in Table 4, refers to text that was amended or modified following Stage 4.

The finding that charity websites focused on different symptoms to caregivers during the advisory board meeting was interesting and raises the question as to how best elicit feedback on symptoms: asking questions a particular way may encourage a focus on deficit versus a focus on what the patient can still do. Indeed, the inclusion of the ability to understand simple words in the bedridden health state, and to "follow objects with their eyes and recognise and smile at people" in the head control health state are arguably important statements to have included in the descriptions, to highlight capabilities as well as impairments. Similarly, in this study caregiver engagement was provided through structured group discussion at an advisory board, compared with one to one telephone interviews. Both are qualitative methods of gathering caregiver perspectives and, thus, provide richer insight than is possible via, for example a survey on its own. However, we suggest that enabling interactions amongst the caregivers may yield additional insights compared with one-to-one interviews. In the social science literature, the general consensus is that focus groups encourage interaction between participants, who respond to and comment on one another's contributions, which generates richer data. ${ }^{8}$

It should be noted that the input into and the review of the vignettes was undertaken by participants (parents/caregivers and clinicians) drawn from only 5 countries (UK, USA, France, Portugal and Spain). This was inevitable given the extremely low prevalence of AADC deficiency globally. However, although the development process lends itself easily to the use of the vignettes in these countries (including a planned study in France), given the variety of healthcare systems around the world, including variations in the quality of care and availability of support, the focus on these countries may have the potential to limit the generalisability of the results and may impact on the use of the vignettes in other countries. On the other hand, this needs to be balanced, in the context of the rarity of the condition, against the fact that the supporting literature used to inform the basis of the vignettes was drawn from sources such as the international consensus guidelines $^{1}$ and patient database (http://www.biopku.org/ jake/JAKE Details.asp), and therefore reflect the key symptoms and signs of AADC deficiency globally.

\section{Conclusion}

In the next stage of the study, the vignettes will be used in both a TTO and SG study to be conducted in both the UK and France, to elicit utilities for use in an economic model. A further stage of vignette review will be included with French clinicians, to ensure that they are valid for use within the French study. As with any such study, the utilities generated will only be as good as they are robust. Whilst in this study 5 stages of development was undertaken to try and more reliably capture what it is like to live with AADC deficiency, the number of caregivers and clinical experts involved was still small, a problem not uncommon in rare disease utility studies. Given the importance of utilities due to their inclusion in cost utility analyses, with 
ramifications for funding decisions, further research into the issues identified in this study would be valuable: triangulation of evidence, transparency regarding symptoms excluded and included, and whether to use one to one interviews or group discussions.

\section{Acknowledgments}

The authors are grateful to parents and caregivers who gave their time to describe their experiences of having a child with AADC deficiency and for reviewing the vignettes at the various stages of the study, as well as to the clinicians for their thoughts and input.

\section{Disclosure}

$\mathrm{ABS}$ and $\mathrm{AH}$ (YHEC) report no conflicts of interest in this work. YHEC was commissioned by PTC Therapeutics to undertake the work described in this study. YHEC is a private limited company owned wholly by the University of York. KB is an employee of PTC Therapeutics, the manufacturer of PTC-AADC, a candidate gene therapy for the treatment of AADC deficiency. The authors report no other conflicts of interest in this work.

\section{References}

1. Wassenberg T, Molero-Luis M, Jeltsch K, et al. Consensus guideline for the diagnosis and treatment of aromatic 1-amino acid decarboxylase (AADC) deficiency. Orphanet J Rare Dis. 2017;12(1):12. doi:10.1186/ s13023-016-0522-z

2. Kojima K, Nakajima T, Taga N, et al. Gene therapy improves motor and mental function of aromatic 1-amino acid decarboxylase deficiency. Brain. 2019;142(2):322-333. doi:10.1093/brain/awy331

3. Chien YH, Lee NC, Tseng SH, et al. Gene therapy in children with AADC deficiency with AGIL-AADC leads to de novo dopamine production and sustained improvement in motor milestones over 5 years. Neurology. 2018;90(15 Supplement):S29.008.

4. Dolan P. Modeling valuations for EuroQol health states. Med Care. 1997;35(11):1095-1108. doi:10.1097/00005650-199711000-00002

5. Torrance GW. Measurement of health state utilities for economic appraisal. $J$ Health Econ. 1986;5:1-30. doi:10.1016/0167-6296(86) 90020-2

6. Bansback N, Brazier J, Tsuchiya A, Anis A. Using a discrete choice experiment to estimate health state utility values. $J$ Health Econ. 2012;31:306-318. doi:10.1016/j.jhealeco.2011.11.004

7. Brun L, Ngu LH, Keng WT, et al. Clinical and biochemical features of aromatic L-amino acid decarboxylase deficiency. Neurology. 2010;75 (1):64-71. doi:10.1212/WNL.0b013e3181e620ae

8. Willig C. Introducing Qualitative Research in Psychology: Adventures in Theory and Method. 3rd ed. Maidenhead, Berkshire: McGraw-Hill Education (UK); 2013.
Patient Related Outcome Measures

\section{Publish your work in this journal}

Patient Related Outcome Measures is an international, peer-reviewed, open access journal focusing on treatment outcomes specifically relevant to patients. All aspects of patient care are addressed within the journal and practitioners from all disciplines are invited to submit their work as well as healthcare researchers and patient support groups.

\section{Dovepress}

The manuscript management system is completely online and includes a very quick and fair peer-review system. Visit http://www. dovepress.com/testimonials.php to read real quotes from published authors. 